\title{
Management Practices to Prevent Wax Moth, a Pest of Honeybees in Ethiopia
}

\author{
Alemayehu Gela ${ }^{1}$, Taye Negera ${ }^{1}$, Amssalu Bezabh, Deselegn Begna ${ }^{1}$ \\ ${ }^{1}$ Oromia Agricultural Research Institute, Holeta Bee Research Centre
}

\begin{abstract}
The study was designed to identify effective wax moth preventive and/ or control management practice(s) to minimize the damage inflected by this pest. The management preventive practices: strengthening honeybee colonies via feeding, reducing the suppers and un occupied combs, the combination of these practices and trapping wax moths that are intended to enter beehives were evaluated for their effectiveness to prevent wax moth infestation for three years and compared with control (group of colonies that did not receive treatment). Statistical significant variation was observed among the treatments $(p<0.05)$. Significantly low wax moth infestation level and high honey yield were recorded when all management packages (feeding, reducing super and unoccupied frames) were applied compared to control $(P<0.05)$. Wax moth infestation level was reduced by $82.3 \%$ using this package. The prevalence of wax moth is higher during dearth period (Decmber to March) in the study period.
\end{abstract}

Keywords: Honey, infestation, losses, prevalence, wax

\section{INTRODUCTION}

Wax moth is one of the troublesome pests existing in Ethiopia. It is found in all parts of the country in Ethiopia (though more serious in hot areas [1]. Wax moth is an insect in the order Lepidoptera that can eat and destroy the beeswax combs where the bees can store pollen, honey and lay eggs for their normal activity [1]. There are two species of moth - the greater wax moth, Galleria mellonella and the lesser wax moth, Achroia grisella. Wax moths occur in all beekeeping areas but are more active in the warmer parts of the country. They generally cause little damage in temperatures below $27^{\circ} \mathrm{C}$, but above this temperature they become active and spread rapidly [2]. It is the wax moth larvae (Caterpillar) that are very destructive and can quickly destroy stored bees wax combs. Wax moths cause loss of about 459.9 and 7.9 Metric tones of crude honey and pure wax in three zones of Oromia Regional State (West showa, East showa \& South west showa) alone in a year [3].

An effective method of control of this pest has not been developed. Physical, chemical, and biological methods are imperfect [4] and [5]. Moreover, the use of synthetic pheromones in the field to trap the female moths was not successful [6].However, the response of females to the synthetic bait in laboratory tests was not as high as their response to live males [7] and in field tests this mixture was practically inactive [8]. This calls for developing preventive method(s) to safe the loss encountered due to this pest. The study was designed with the specific objectives of select and adopts easy and effective wax moth preventive and/ or control management practice(s) to minimize the damage.

\subsection{Description of the Study Area}

The study was conducted at Bako Agricultural Research Center apiary site, located in mid-altitude sub-humid zone of the western part of Ethiopia. It is one of the administrative regions under West shoa zone of Oromia regional national State.

\section{MATerials AND MethodS}

The management preventive practices (strengthening honeybee colonies via feeding, reducing the suppers and placing the frames and boxes in well aerated areas during the dearth period, removing the unoccupied frames and simultaneously all the above together) and trapping wax moths using before enter beehives were evaluated for their effectiveness to prevent wax moth infestation. These management practices were selected as they were easily practiced under farmer's condition. The efficiency of these treatments was compared with the control ones (colonies left untreated). 
A total of thirty hone bee colonies used, were five honey bee colonies were assigned to each treatment, feeding, reducing supers, reducing unoccupied frames, all management practices in one, trapping. All the colonies were checked to be free of wax moth before the experiments stared. Reducing the suppers were applied for those honeybee colonies having one or more suppers. Suppers was reduced on time when the colonies were dwindled and the removed frames and boxes were placed in well-aerated place and reused when necessary. Fed a $1 \mathrm{~kg}$ of sugar solution (1 sugar: 1 water) once every month of the dry season. The colonies were diagnosis for wax moth infestation every month while feeding. Removing the unoccupied frames were applied to colonies in the base hive. When colonies dwindled and move to one side of the hive, the frames that was not occupied by honeybees were removed and placed in well-aerated place and was reused when necessary. For all management practices, each colony was fed, suppers were reduced when the colonies are dwindled and the frames that were not occupied by honeybees were bee removed using procedures indicated under each treatment above.

Wax moth trapping was done in separate site away from the other treatments. 1 cup of water, 1 cup of sugar, 1 banana peel and $1 / 2$ cup vinegar was added in to 2-liter plastic coke bottle that is drilled a 1inch hole just below the slop on the neck and waited a few days till it starts to ferment. Then the fermented solution was tied in to a tree close to the experimental honeybee colonies to attract adult wax moth that intend to enter the hives. Number of adult wax moths drawn in the solution was recorded. Control group placed adjacent to the four management practices and used to evaluate the effects of management practices. The control groups never received any management practices mentioned in above treatments and were used to compare the results of the treatments.

\section{RESULT AND DISCUSSION}

The brood area measurement was significant difference $(\mathrm{p}<0.05)$ higher for all management practice than the rest. The pollen area measurement was significant difference $(p<0.05)$ higher for trapping practice than the rest of the treatments and also the nectar area measurement was significant difference $(p<0.05)$ higher for reducing super practice than the rest of the treatment (table 1). The number of infected combs was significant difference $(\mathrm{p}<0.05)$ lower for management practice than the rest of the treatments (table 1). The bee population measurement was significant difference ( $\mathrm{p}<$ 0.05 ) higher for all management practice than the rest treatment. The result of the study indicated that the brood area measurement had significantly $(\mathrm{p}<0.05)$ higher in year three than the rest.

The result of the study indicated that the pollen and nectar store had significantly $(p<0.05)$ higher in year three than the rest years. Also low number infected combs were occurred in year three than the rest years (table 2).

The higher total mean of brood area measurement, pollen, and nectar and bee population scored in month of September-November, while high infected comb occurred in month December -March. Low comb infection was occurred in month June, September, October and November of study ever year. The study result showed that wax moth causes significant loss of honey, bees wax and honeybee colonies. The infected honeybee colonies are either absconded (56-75\%) or dwindled (Dessalegn, 2001).

As observed from this experiment, the number of bees, nectar, pollen, brood and honey yield were increasing after the application of the control methods. Also the number of infected combs were decrease during the application these control methods when compare with the control groups. In general, among applied control method, all management practice shows that increasing the amount of brood, nectar and number of bee population than the other treatments.

Table1. Effect of wax moth control treatment methods on honey bee and bee products

\begin{tabular}{|l|l|l|l|l|l|l|}
\hline $\begin{array}{l}\text { Treatment } \\
\text { group }\end{array}$ & $\begin{array}{l}\text { Mean number } \\
\text { of brood }\end{array}$ & $\begin{array}{l}\text { Mean number } \\
\text { of pollen }\end{array}$ & $\begin{array}{l}\text { Mean number } \\
\text { of nectar }\end{array}$ & $\begin{array}{l}\text { Mean number } \\
\text { of infected } \\
\text { comb }\end{array}$ & $\begin{array}{l}\text { Mean number } \\
\text { of bee pop }\end{array}$ & $\begin{array}{l}\text { Mean of } \\
\text { honey yield }\end{array}$ \\
\hline Feeding & $23.72 \pm 2.28^{\mathrm{b}}$ & $11.02 \pm 1.40^{\mathrm{b}}$ & $56.63 \pm 4.9^{\mathrm{ab}}$ & $2.73 \pm 0.24^{\mathrm{ab}}$ & $71.01 \pm 3.84^{\mathrm{b}}$ & $9.88 \pm 2.35^{\mathrm{b}}$ \\
\hline $\begin{array}{l}\text { Reducing un } \\
\text { occupied } \\
\text { frame }\end{array}$ & $24.41 \pm 1.93^{\mathrm{b}}$ & $12.33 \pm 1.61^{\mathrm{b}}$ & $50.29 \pm 3.3^{\mathrm{ab}}$ & $3.1 \pm 0.21^{\mathrm{ab}}$ & $68.95 \pm 3.28^{\mathrm{b}}$ & $5.50 \pm 0.87^{\mathrm{b}}$ \\
\hline $\begin{array}{l}\text { Reducing } \\
\text { super }\end{array}$ & $30.80 \pm 2.8^{\mathrm{ab}}$ & $15.5 \pm 1.99^{\mathrm{ab}}$ & $56.47 \pm 4.2^{\mathrm{ab}}$ & $2.9 \pm 0.20^{\mathrm{ab}}$ & $68.40 \pm 3.64^{\mathrm{b}}$ & $10.1 \pm 1.33^{\mathrm{a}}$ \\
\hline
\end{tabular}


Management Practices to Prevent Wax Moth, a Pest of Honeybees in Ethiopia

\begin{tabular}{|l|l|l|l|l|l|l|}
\hline \hline $\begin{array}{l}\text { All } \\
\text { management }\end{array}$ & $34.38 \pm 2.86^{\mathrm{a}}$ & $13.84 \pm 1.87^{\mathrm{b}}$ & $65.01 \pm 5.21^{\mathrm{a}}$ & $1.3 \pm 0.11^{\mathrm{b}}$ & $90.54 \pm 5.43^{\mathrm{a}}$ & $13.8 \pm 2.6^{\mathrm{a}}$ \\
\hline Control & $23.73 \pm 2.80^{\mathrm{b}}$ & $13.75 \pm 1.95^{\mathrm{b}}$ & $43.55 \pm 4.5^{\mathrm{b}}$ & $7.34 \pm 0.5^{\mathrm{a}}$ & $65.87 \pm 5.2^{\mathrm{b}}$ & $5.25 \pm 1.25^{\mathrm{b}}$ \\
\hline Trapping & $23.84 \pm 2.1^{\mathrm{b}}$ & $20.39 \pm 2.4^{\mathrm{a}}$ & $58.26 \pm 5.4^{\mathrm{ab}}$ & $5.78 \pm 0.34^{\mathrm{a}}$ & $78.68 \pm 4.72^{\mathrm{ab}}$ & $9.8 \pm 2.23^{\mathrm{b}}$ \\
\hline
\end{tabular}

Mean followed by the same letter in the same column are not significantly different, $p>0.05$

Table2. Effect of wax moth control methods on honey bee, nectar, pollen and brood with the year

\begin{tabular}{|c|l|l|l|l|l|l|}
\hline Year & $\begin{array}{c}\text { Mean number } \\
\text { of brood }\end{array}$ & $\begin{array}{c}\text { Mean number } \\
\text { of pollen }\end{array}$ & $\begin{array}{c}\text { Mean number } \\
\text { of nectar }\end{array}$ & $\begin{array}{c}\text { Mean number } \\
\text { of infected } \\
\text { comb }\end{array}$ & $\begin{array}{c}\text { Mean number } \\
\text { of bee pop. }\end{array}$ & Honey yield \\
\hline Year 1 & $23.84 \pm 1.33 \mathrm{~b}$ & $7.23 \pm 0.6 \mathrm{~b}$ & $64.5 \pm 3.13 \mathrm{a}$ & $5.16 \pm 0.3 \mathrm{a}$ & $71.82 \pm 3.39 \mathrm{a}$ & - \\
\hline & & & & & & \\
\hline Year 2 & $26.18 \pm 1.86 \mathrm{ab}$ & $15.81 \pm 1.42 \mathrm{a}$ & $55.09 \pm 3.63 \mathrm{~b}$ & $3.5 \pm 0.22 \mathrm{~b}$ & $76.78 \pm 3.1 \mathrm{a}$ & $10.5 \mathrm{a}$ \\
\hline & & & & & & \\
\hline Year 3 & $29.54 \pm 1.88 \mathrm{a}$ & $18.54 \pm 1.47 \mathrm{a}$ & $48.33 \pm 2.97 \mathrm{~b}$ & $3.02 \pm 0.20 \mathrm{~b}$ & $73.43 \pm 3.04 \mathrm{a}$ & $10.56 \mathrm{a}$ \\
\hline
\end{tabular}

Mean followed by the same letter in the same column are not significantly different; $p>0.05$

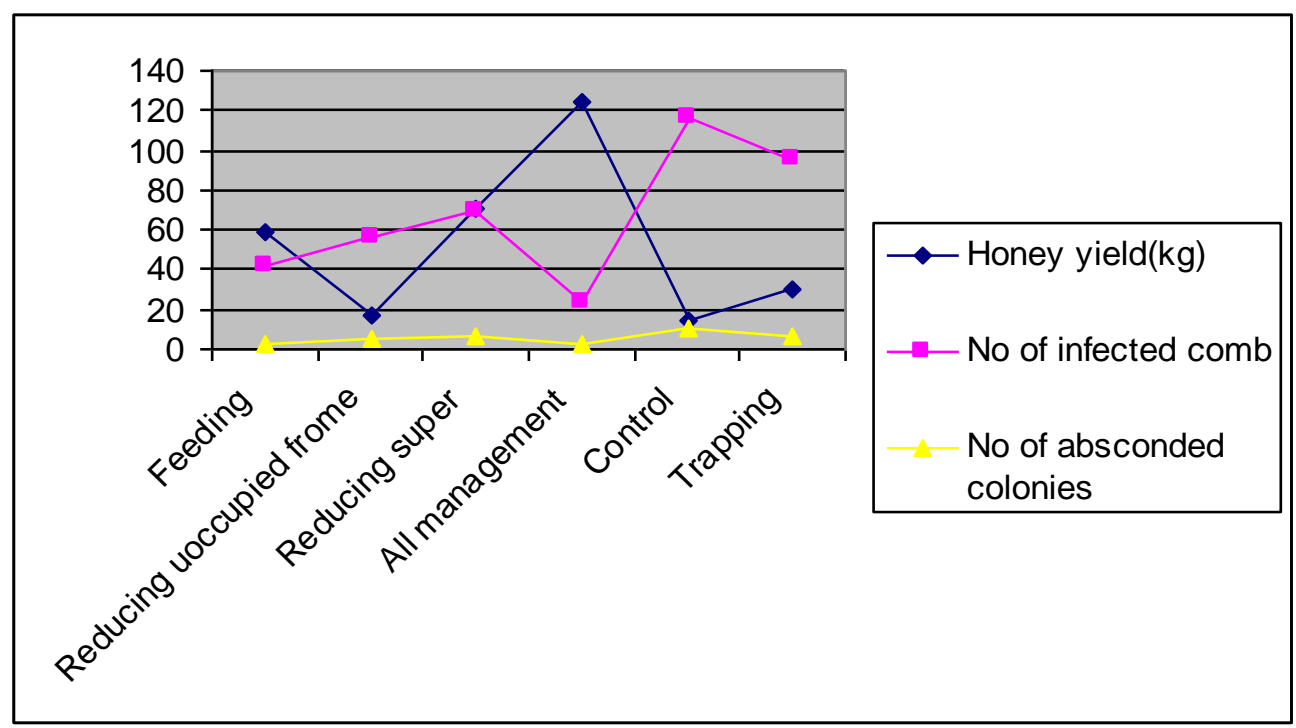

Figure1. Effect of wax moth control methods on honey bee, nectar, pollen, infected combs and brood with the months per year

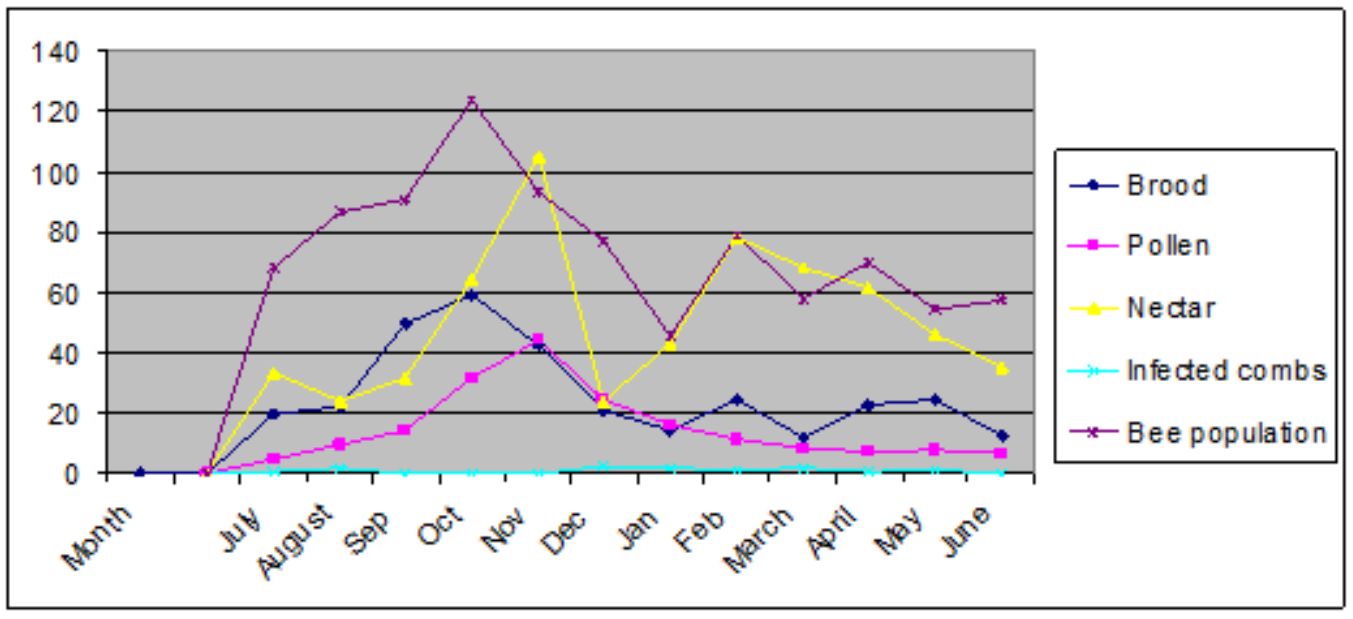

Figure2. Effect of wax moth on honeybee colonies, honey yield and bees wax

The high honey yield recorded using all management practices, feeding and reducing super during the study years. From this result observed that high comb infection recorded with control group which did not treated and there also some number of honey bee colonies absconding after fed was given. A fewer number of honey bee colonies were absconded throughout using all manage mental practices (feeding, reducing and adding unoccupied frame, reducing super). 


\section{Conclusion}

Wax moth can be an extremely destructive pest and can destroy empty combs in a very short space of times; beekeepers across the country can now have access to a management practice control for one of their biggest out-of- season pests. The control methods revealed that, all management practices (feeding, reducing and adding unoccupied frame, reducing super) are the dominant wax moth for reducing in number infected combs and strongly increment of pollen, nectar, brood, bee population and honey yields. It also interesting that to note that giving fed in dearth periods is a pre-dominant wax moth control methods. Therefore, this study recommends the importance of encouraging of the beekeeper farmers in hot and humid areas to develop the aforementioned wax moth control methods using all management practices (feeding, reducing and adding unoccupied frame, reducing super) to promote improved beekeeping so as to spread their income and thereby improve their livelihoods.

\section{ACKNOWLEDGEMENTS}

We greatly acknowledge Ethiopian institute of Agricultural Research for financial assistance. We are very grateful to W/ro Inani B/ward, Ms. Gete Dhaba, W/ro Shewanesh Negera, and Mr. Hiwot Birhanu for their respective contributions. We would also like to thank Mr. Zewudu Ararso for data analyzing and interpretation.

\section{REFERENCES}

[1] B. Desalegn, and K. Yosef, "Survey of honeybee pests \& pathogens in Addis Ababa region". Published in 5th Proceedings National Conference of Ethiopian Beekeeping Association. Addis Ababa, Ethiopia, 2005

[2] E.Crane, "Beekeeping as a sustainable practice: past, present and future" New Zealand Beekeeper,vol. 7, no.8, pp. 43-51,2007

[3] B. Amsalu, and B. Desalegn, "Survey of honeybee pest and Pathogen in South and Southwest parts of Ethiopia". Published in 16th Proceedings of Ethiopian Veterinary Association. Pp. 8693, 2001

[4] F. Smith, "Beekeeping in tropics," Bee world. vol. 63, no. 11, pp. 312- 319, 1970

[5] H. Burges "Control of wax moth: Physical, Chemical and biological met-hods" Bee World, vol.59.no.4, 129-138, 1978

[6] F. Eishen, A. Dietz and J. Brower, "Effect of again on the mating competitiveness of irradiated male greater wax moth (Lep.,Pyralidae)" Journal of Economic Entomology,vol.77, no. 6, pp.1534-1536, 1984

[7] R. Jafari S.Goldasteh and S .Afrogheh, "Control of the wax moth Galleria mellonella L. (Lepidoptera: Pyralidae) by the male sterile technique (MST)" Archives of Biological Sciences, vol. 62 , no. 2 ,pp.309-313,2010

[8] T. Smith, "External morphology of the larva, pupa and adult of the wax moth Galleria mellonella L.” Journal of the Kansas Entomological Society,vol 38,pp. 287-310, 1965 